\title{
Water dispersible microbicidal cellulose acetate phthalate film
} A Robert Neurath*, Nathan Strick and Yun-Yao Li

\author{
Address: Biochemical Virology Laboratory, The Lindsley F. Kimball Research Institute of the New York Blood Center, New York, NY 10021, USA \\ Email: A Robert Neurath* - arneurath@att.net; Nathan Strick - nstrick@nybloodcenter.org; Yun-Yao Li - yli@nybloodcenter.org \\ * Corresponding author
}

Published: I 4 November 2003

BMC Infectious Diseases 2003, 3:27
Received: 0I August 2003

Accepted: 14 November 2003

This article is available from: http://www.biomedcentral.com/l47I-2334/3/27

(C) 2003 Neurath et al; licensee BioMed Central Ltd. This is an Open Access article: verbatim copying and redistribution of this article are permitted in all media for any purpose, provided this notice is preserved along with the article's original URL.

\begin{abstract}
Background: Cellulose acetate phthalate (CAP) has been used for several decades in the pharmaceutical industry for enteric film coating of oral tablets and capsules. Micronized CAP, available commercially as "Aquateric" and containing additional ingredients required for micronization, used for tablet coating from water dispersions, was shown to adsorb and inactivate the human immunodeficiency virus (HIV-I), herpesviruses (HSV) and other sexually transmitted disease (STD) pathogens. Earlier studies indicate that a gel formulation of micronized CAP has a potential as a topical microbicide for prevention of STDs including the acquired immunodeficiency syndrome (AIDS). The objective of endeavors described here was to develop a water dispersible CAP film amenable to inexpensive industrial mass production.

Methods: CAP and hydroxypropyl cellulose (HPC) were dissolved in different organic solvent mixtures, poured into dishes, and the solvents evaporated. Graded quantities of a resulting selected film were mixed for $5 \mathrm{~min}$ at $37^{\circ} \mathrm{C}$ with HIV-I, HSV and other STD pathogens, respectively. Residual infectivity of the treated viruses and bacteria was determined.

Results: The prerequisites for producing CAP films which are soft, flexible and dispersible in water, resulting in smooth gels, are combining CAP with HPC (other cellulose derivatives are unsuitable), and casting from organic solvent mixtures containing $\approx 50$ to $\approx 65 \%$ ethanol (EtOH). The films are $\approx 100 \mu$ thick and have a textured surface with alternating protrusions and depressions revealed by scanning electron microscopy. The films, before complete conversion into a gel, rapidly inactivated HIV-I and HSV and reduced the infectivity of non-viral STD pathogens $>I, 000$-fold.

Conclusions: Soft pliable CAP-HPC composite films can be generated by casting from organic solvent mixtures containing $\mathrm{EtOH}$. The films rapidly reduce the infectivity of several STD pathogens, including HIV-I. They are converted into gels and thus do not have to be removed following application and use. In addition to their potential as topical microbicides, the films have promise for mucosal delivery of pharmaceuticals other than CAP.
\end{abstract}

\section{Background}

Polymers, used in the past as pharmaceutical excipients and in drug delivery, are increasingly being considered for specific therapeutic and prophylactic applications [1-5]. They appear promising for topical applications as micro- bicides to prevent infection by sexually transmitted disease (STD) pathogens, including the human immunodeficiency virus (HIV-1) [6]. One of these promising polymeric microbicides is cellulose acetate phthalate (CAP) [7-14]. CAP has been used for enteric film coating 
of tablets and capsules [15] and thus has a well-established safety record for human use. CAP is not soluble in water at $\mathrm{pH}<\approx 5.8$. For this reason, it must be used in a micronized form for both tablet coating from water dispersions, and as a topical microbicide. Micronization is accomplished by pseudolatex emulsion processes [1624]. A micronized form of CAP available commercially under the trade name "Aquateric" (FMC Corporation, Philadelphia, Pennsylvania, USA) (containing 63 to $70 \%$ CAP, Poloxamers and acetylated monoglycerides) in appropriate gel formulations was shown to inactivate HIV-1 and several other STD pathogens in vitro and in animal models [7-9,14]. Micronized CAP was shown to be the only candidate microbicide having the capacity to remove rapidly by adsorption HIV-1 from physiological fluids and render the virus noninfectious.

Microbicidal gels with or without contraceptive activity have some disadvantages. They need applicators for topical delivery adding to cost [25] and generating disposal problems. Furthermore distinct applicator dimensions may be preferred by distinct populations, and their packaging and size may not be optimal for discretion related to purchase, storage and use. Microbicidal gel production and applicator manufacture are likely to occur at different sites, and high capacity applicator filling equipment is required for large volume production. These drawbacks can be overcome by unit dose biodegradable films dispersible in water and having the following properties: 1) the microbicidal activity is a built-in property of the films, i.e. the active ingredient is an integral structural component of the films; 2) the films absorb physiological fluids and then disintegrate; 3 ) infectious agents bind to the resulting structures and become rapidly inactivated; 4) the films are converted into a soft gel which does not have to be removed; 5) simplicity of use and no "messiness"; 6) small packaging, facilitating discretion related to purchase, storage and portability; 7) low production price and suitability for use in developing countries; 8) amenability to industrial mass production; 9) Integration of manufacture and packaging; 10) Low cost of transportation due to the small size and weight of a unit dosage; 11) capacity to augment a healthy acidic vaginal environment and 12) potential for modifications leading to their application as rectal microbicides. A device having most of these properties is a sponge prepared by freeze-drying a foam generated from a water suspension of Aquateric in a solution of bioadhesive partially substituted ethers of cellulose (e.g. hydroxypropyl methylcellulose, methylcellulose, hydroxyethyl cellulose and hydroxypropyl cellulose (HPC). Alternatively, the sponges can be prepared by freeze-drying a microemulsion [26] of CAP in ethyl acetate mixed with a water solution of one of the cellulose ethers. These sponges contained 34 to $40 \%$ of the active ingredient, CAP. The advantages of the unit dose sponges are extenuated by the relatively high cost of freeze-drying. This would limit their use as a microbicide in developing countries. Therefore, alternative approaches had to be explored, the objective being the development of a unit dose water dispersible device, the production of which does not require freeze drying.

Water soluble or dispersible films are being used for drug delivery onto mucosal surfaces [27-30]. Films are also an established delivery vehicle for the administration of vaginal products. Contraceptive films have been marketed since the 1980's and there have been no concerns about the safety of this method of administration. There was an $86 \%$ compliance with film use in a phase III human efficacy trial of a contraceptive film containing Nonoxynol-9 (N-9). Although the trial failed due to the undesirable properties of N-9, the very high compliance rate shows that films represent a microbicide delivery method which is easy and acceptable [31-34]. These findings have led us to develop CAP based microbicidal films.

The HIV-1 epidemic is maintained and progresses mostly due to sexual transmission of the virus [35] and is facilitated by prior infections with non-viral STD pathogens [36-40] and herpesviruses (HSV) [41-43]. The estimated annual worldwide incidence of non-viral STD pathogens is over 330 million [44]. About $20 \%$ of the United States population has been infected with HSV-2, the prevalence of such infections being even higher in developing countries [45]. Organisms associated with bacterial vaginosis (BV) also increase the susceptibility to HIV-1 infection [46]. For these reasons, broad spectrum microbicides acting not only against HIV-1 but also against other STD pathogens would be expected to have the greatest impact in preventing STDs including AIDS. Micronized CAP was shown to act in vitro [7,10-14,47-49] and in some animal model systems $[8,9]$ as a compound with broad spectrum activities. This had to be confirmed for the film formulation of CAP.

\section{Methods}

\section{Preparation and physical properties of CAP-HPC film}

CAP, HPC (150-400 cps, NF, Spectrum, New Brunswick, New Jersey, USA), HPC (4,000-6,500 cps, NF, Spectrum) and glycerol were dissolved in acetone-ethanol (EtOH) $4: 6$ at final concentrations of $2,1,1$, and $1 \%(\mathrm{w} / \mathrm{w})$, respectively. The viscous liquids were poured into Teflon ${ }^{\circledR}$ coated steel or aluminum foil dishes $\left(0.425 \mathrm{~g} / \mathrm{cm}^{2}\right)$ which were subsequently kept for $16 \mathrm{hr}$ at $40^{\circ} \mathrm{C}$ followed by $1 \mathrm{hr}$ in a vacuum oven at $50^{\circ} \mathrm{C}$ to dry the films.

To measure the kinetics of film conversion into a gel, the film was shredded into $\approx 1 \mathrm{~mm}^{2}$ pieces in a Guardian Cross-Cut Shredder (Quartet GBC, Skokie, Illinois, USA) and added at $75 \mathrm{mg} / \mathrm{ml}$ to either water or human seminal 
fluid (New England Immunology Associates, Cambridge, Massachusetts, USA). Viscosity was measured in a DV-3 P $\mathrm{R}$ digital viscometer (Anton Paar GmbH, Graz, Austria) using a TR-8 spindle at speeds decreasing from 200 to 2 r.p.m.

Imaging of cast films was performed with a JEOL 6500 Field Emission scanning electron microscope (JEOL USA, Inc., Peabody, Massachusetts, USA) at a magnification of $5,000 \times$. Scanning white light interferometric microscopy was performed on both sides of the film at a magnification of $25 \times$ (Fig. 1b,1c). CAP particles obtained after complete dispersion of the film were pelleted by centrifugation at $10,000 \times \mathrm{g}$ for $5 \mathrm{~min}$, washed with water to remove excess HPC, and freeze dried. The particles were dispersed in water and measured by automated scanning electron microscopy using a JEOL 6400 scanning electron microscope coupled with a NORAN Voyager system (NORAN Instruments, Inc., Middleton, Wisconsin, USA). Imaging of the particles on a carbon substrate was performed using the JEOL 6500 electron microscope.

\section{Measurements of infectivity of HIV-I and herpesviruses (HSV)}

To measure HIV-1 infectivity, virus was precipitated from tissue culture media containing 10\% fetal bovine serum with polyethylene glycol 8000 (final concentration 10 $\mathrm{mg} / \mathrm{ml}$ ). The pellet containing virus was dissolved in 225 $\mu \mathrm{l}$ aliquots of $0.14 \mathrm{M} \mathrm{NaCl}, 0.01 \mathrm{M}$ Tris(hydroxymethyl)aminomethane, $\mathrm{pH} 7.2$ (TS). The aliquots were prewarmed to $37^{\circ} \mathrm{C}$ and precut pieces of film $\mathrm{H}$ were added. After $5 \mathrm{~min}$ at $37^{\circ} \mathrm{C}, 1.225 \mathrm{ml}$ of tissue culture medium was added and the mixtures were centrifuged for $1 \mathrm{hr}$ at 14,000 r.p.m. in an Eppendorf 54156 microfuge (Brinkmann Instruments, Inc., Westbury, New York, USA) to pellet the virus. The virus was redissolved, serially diluted twofold $(2 \times$ to $2,048 \times)$, and the dilutions tested for infectivity using HeLa-CD4-LTR- $\beta$-gal and MAGI-CCR5 cells for HIV-1 IIIB and HIV-1 BaL, respectively. Virus replication was quantitated by measuring $\beta$-galactosidase ( $\beta$-gal) activity in cell lysates as described elsewhere in detail [14]. In a parallel series of experiments, residual film $\mathrm{H}$ was removed by centrifugation at 2,000 r.p.m. for $5 \mathrm{~min}$ from the film-virus mixtures before pelleting the virus at 14,000 r.p.m. The infectivities of control and film H treated HSV1 and HSV-2, respectively, were measured under similar conditions as described for HIV-1 [7]. HSV-1 was a recombinant virus, vgCL5, in which the expression of $\beta$-gal is under the control of the late gene $\mathrm{C}$ regulatory region. Vero cells were used for infection which was monitored by measuring $\beta$-gal activity. ELVIS HSV cells (Diagnostic Hybrids, Inc., Athens, Ohio, USA), containing a LacZ gene placed behind an inducible HSV promoter, were used for infection by HSV-2. Infection was determined by measuring $\beta$-gal.

\section{Inactivation of non-viral STD pathogens and bacteria associated with bacterial vaginosis (BV)}

The bacterial strains and the corresponding growth media were obtained from the American Type Culture Collection (ATCC, Manassas, Virginia, USA) and were the same as described earlier $[7,10]$. Mycoplasma capricolum was ATCC \#23205. Graded quantities of film H (0 to $150 \mathrm{mg} / \mathrm{ml}$ ) were added to suspensions of the respective bacteria $(8 \times$ $10^{8}$ to $1 \times 10^{9} / \mathrm{ml}$ in TS) pre-warmed to $37^{\circ} \mathrm{C}$. After $5 \mathrm{~min}$ at $37^{\circ} \mathrm{C}$, the suspensions were diluted 10 -fold in the appropriate growth medium, centrifuged to pellet the bacteria which were then resuspended in the original volume of growth medium. Serial 10-fold dilutions in the appropriate growth media were made, and after incubation at $37^{\circ} \mathrm{C}\left(30^{\circ} \mathrm{C}\right.$ for Haemophilus ducreyi) for $20 \mathrm{hr}$ to 5 days, depending on the bacterial strain, turbidity was measured at $600 \mathrm{~nm}$. Serial twofold dilutions $(100 \mu \mathrm{l})$ of control and film $\mathrm{H}$ treated Chlamydia trachomatis were added to 9 $\times 10^{4}$ McCoy cells plated into wells of 96-well microtiter plates. After $48 \mathrm{hr}$, the cells were fixed and stained with fluorescein isothiocyanate labeled monoclonal antibodies to Chlamydia (Diagnostic Hybrids) and the fluorescent inclusion bodies were counted following the procedures provided by the manufacturer. The percentages of residual infectivity for each film treated organism were calculated by comparing the respective dose response curves with readout vs. dilution curves corresponding to each of the respective control organisms.

\section{Results \\ Casting of CAP films}

CAP is moisture sensitive during long term storage [15]. Therefore, organic solvents had to be used for film casting. This appeared counterintuitive since CAP films cast from organic solvents are water resistant [15], and start dissolving only at $\mathrm{pH}>\approx 5$.8. Furthermore, none of the mucoadhesive cellulose ethers are soluble in organic solvents which dissolve CAP [15], except for HPC which is soluble in methylene chloride [50]. HPC is also one of the best bioadhesive polymers among cellulose ethers [51]. It was possible to prepare composite CAP (40\%) - HPC (40\%) - glycerol (20\%) films cast from one of the following solvents: ethyl acetate; glacial acetic acid; methylene chloride; and acetone/EtOH 9:1 (v/v). The resulting films were hard, brittle and did not disperse in water. It has been reported that the properties of films cast from organic solvents may change by varying the composition of solvent mixtures even though the composition of the dried films is the same [52-56]. Using this approach, we found, surprisingly, that addition of EtOH (final concentrations 50 to $65 \%$ ) to the casting solvents ethyl acetate, $\mathrm{CH}_{3} \mathrm{COOH}$ and acetone, respectively, resulted in films with dramatically altered properties. They were soft, flexible, and dispersed in water, resulting ultimately in smooth gels. The properties of a selected film (designated " $\mathrm{H}^{\prime}$ ) consisting of 

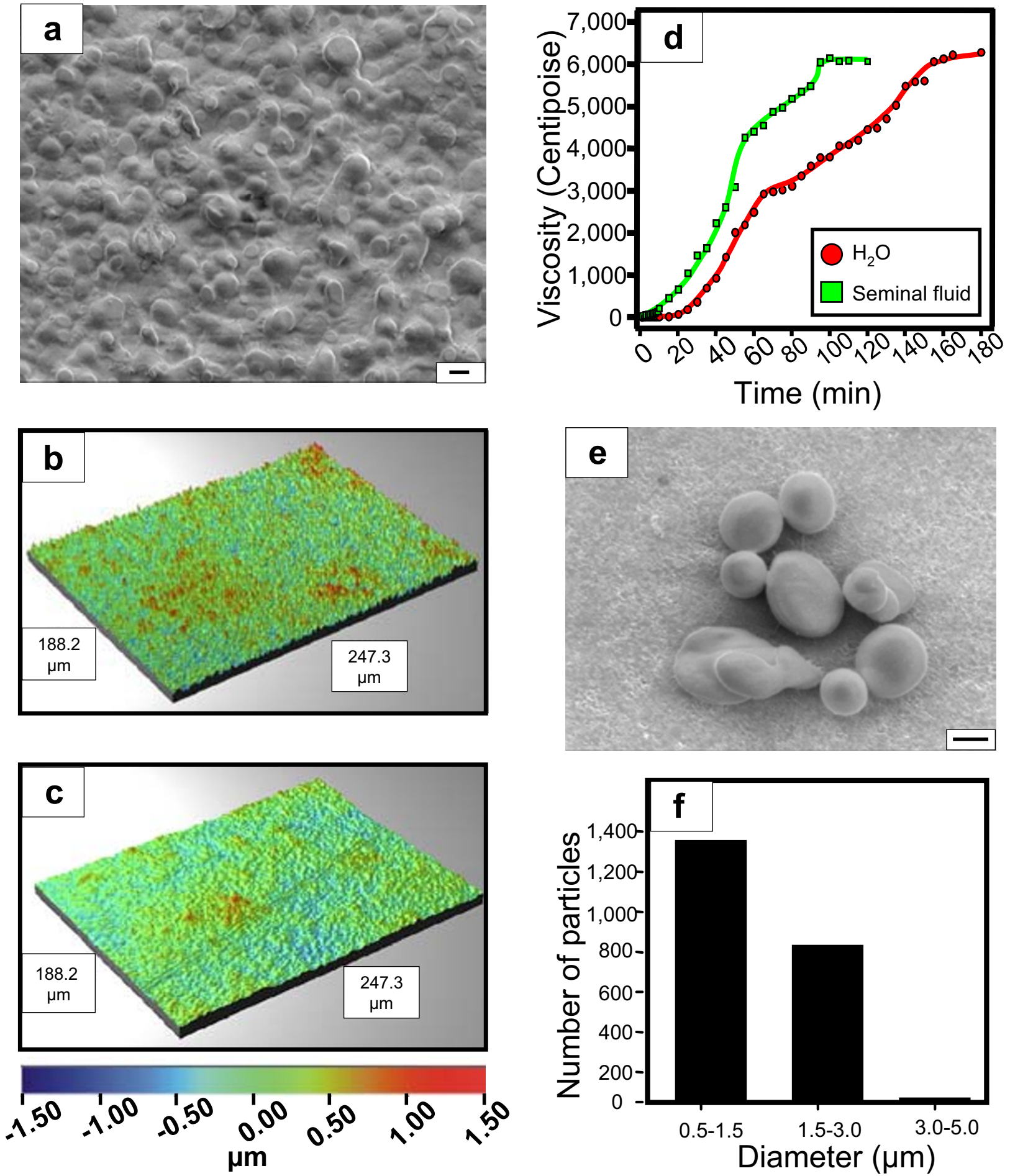

Figure I

Morphology of CAP-HPC composite film $\mathrm{H}$ and of particles after film dispersion in water. a, Scanning electron microscopy of film $\mathrm{H}$ (side "A" exposed to air during drying). b, 3-dimensional (3-D) interactive display of side "A" of film H. c, 3-D interactive display of film $\mathrm{H}$ (side "B" in contact with the casting surface during drying). b, c, Color bar corresponds to elevation scale. $d$, Kinetics of conversion of shredded film $\mathrm{H}$ into a gel as measured by increase of viscosity. e, Scanning electron microscopy of CAP particles from the gel. $f$, Size distribution of the particles. Scale bar for a and e is I $\mu$. 
$40 \% \mathrm{CAP}, 40 \%$ HPC and $20 \%$ glycerol cast from acetone/ EtOH 4:6 are described here.

\section{Physical properties of CAP-HPC film H}

Scanning electron microscopy of film $H$ (thickness $\approx 100$ $\mu$ ) revealed a particle-accumulated layer on one side (A; exposed to air during drying) of the film (Fig. 1a) while the other side was more smooth (results not shown). Side A of the film was textured with alternating protrusions and depressions having a lateral dimension of $\approx 1 \mu$. The 3-dimensional interactive display of both sides of the film (Fig. 1b,1c), analogous to a geographic map showing peaks and valleys, provides a 3-dimensional image of the film. It covers a larger representative surface of the film than does Fig. 1a, and clearly indicates that the surface of the film is not smooth. This is important for the virus inactivating properties of the film before it disintegrates, since the effectiveness of the film in this regard depends on its total surface area accessible to bind viruses or other pathogens. This area is much larger for a film with elevations and depressions (which can accommodate virus particles) as compared with a film which is "truly" flat. Exposure of the film to water resulted in disintegration and formation of smaller particles ultimately convertible into a gel. Mixing of pieces of film in water at low speed resulted in generation of a smooth gel. The only method to measure objectively the kinetics of this transition is viscosimetry. The corresponding results are shown in Fig. $1 \mathrm{~d}$. The conversion to gel was faster in seminal fluid than in water. Scanning electron microscopy revealed particles of micronized CAP in the resulting gel (Fig. 1e). The particles had a size between 0.5 to $3 \mu$ (Fig. 1f), similar to that of CAP particles in gel formulations which were shown to be efficacious against several STD pathogens in in vitro and in vivo experiments [7,10-14,47-49].

\section{Microbicidal activities of CAP-HPC film}

Micronized CAP was shown to inactivate within a few minutes the infectivity of HIV-1, HSV and several nonviral STD pathogens $[7,14]$. CAP in micronized form is the only candidate topical microbicide having the capacity to remove rapidly by adsorption from physiological fluids HIV-1 of both the X4 and R5 biotypes and is likely to prevent virus contact with target cells [14]. The efficiency of adsorption is proportional to the total surface area of the adsorbent. For a given quantity of adsorbent the surface area is a function of particle size of the adsorbent, the total surface of the particles being inversely proportional to particle diameter, i.e. the smaller the particles, the larger is the total surface area of all particles. For this reason, it is desirable that the film disintegrates into the smallest particles possible.

It was of interest to determine whether film $\mathrm{H}$, long before it completely disintegrates in the presence of water, and is converted into a gel, has effects similar to those of micronized CAP. Weighed film aliquots were added to suspension of the respective viruses. After incubation for $5 \mathrm{~min}$ at $37^{\circ} \mathrm{C}$, the infectivity of the residual viruses was determined by serially diluting each virus preparation and adding the respective diluted samples to target cells. Virus production was assessed using a luminescence readout system. Film was not added to control virus preparations (for details see Methods section). Dose response curves (i.e. luminescence vs. virus dilution) for all film treated and control viruses are shown in Fig. 2. The percentages of virus inactivated by the film were calculated from calibration curves relating luminescence to dilutions of each control virus (=red curves for each virus; Fig. 2). At the highest dose of film $(56 \mathrm{mg} / \mathrm{ml}) \geq 99 \%$ inactivation of HIV-1, HSV-1 and HSV-2 was observed within 5 min at $37^{\circ} \mathrm{C}$ (Fig. 2a, 2b,2c,2d). Both HIV-1 IIIB and BaL, viruses utilizing distinct cellular coreceptors, CXCR4 and CCR5, respectively [12], were inactivated. As the film dose was reduced, the extent of virus inactivation diminished and was $89 \pm 4,82 \pm 9,99.7 \pm 0.1$, and $95 \pm 2 \%$ for HIV $-1 \mathrm{IIIB}$, HIV-1 BaL, HSV-1 and HSV-2, respectively, at a dose of 7 $\mathrm{mg} / \mathrm{ml}$. The residual infectivity in all cases was recovered in supernatants after removing film and particles released from it by centrifugation, suggesting that only virus not adsorbed to the film material escaped inactivation. This was confirmed in separate experiments (data not shown). For comparison, the suggested unit dose of film as a microbicide is $\approx 1,000 \mathrm{mg}$. Furthermore, under in vivo conditions (when the virus concentrations are expected to be by one to four orders of magnitude lower than those used here under experimental conditions $[57,58]$, virus removal by adsorption onto the insoluble CAP would be expected to block the complex sequence of events leading to mucosal infection. This would be further augmented by the formation of "dead-end" HIV-1 gp41 six-helix bundles and stripping off of HIV-1 envelope glycoproteins resulting from virus contact with CAP [14].

Film $\mathrm{H}$ also inactivated several non-viral STD pathogens and bacteria associated with BV (Fig. 3). This effect can be attributed to low $\mathrm{pH}$ provided by CAP $[7,10]$, unlike the anti-HIV-1 and anti-HSV-1/-2 effects occurring at both acidic and neutral $\mathrm{pH}[7,13,14]$. This is probably reflected in the diminishing activity of the film as its dose is decreased. While the residual infectivity of all organisms tested was $\leq 0.1 \%$ for film doses $\geq 75 \mathrm{mg} / \mathrm{ml}(\geq 27.7 \mathrm{mg} /$ $\mathrm{ml}$ for Chlamydia trachomatis), smaller film doses were much less effective (notice the logarithmic scale of the ordinate). Gardnerella vaginalis appeared to be the most sensitive to CAP among all organisms tested. The dose effect was not seen for Haemophilus ducreyi, suggesting distinct mechanisms of CAP action on different bacteria. 


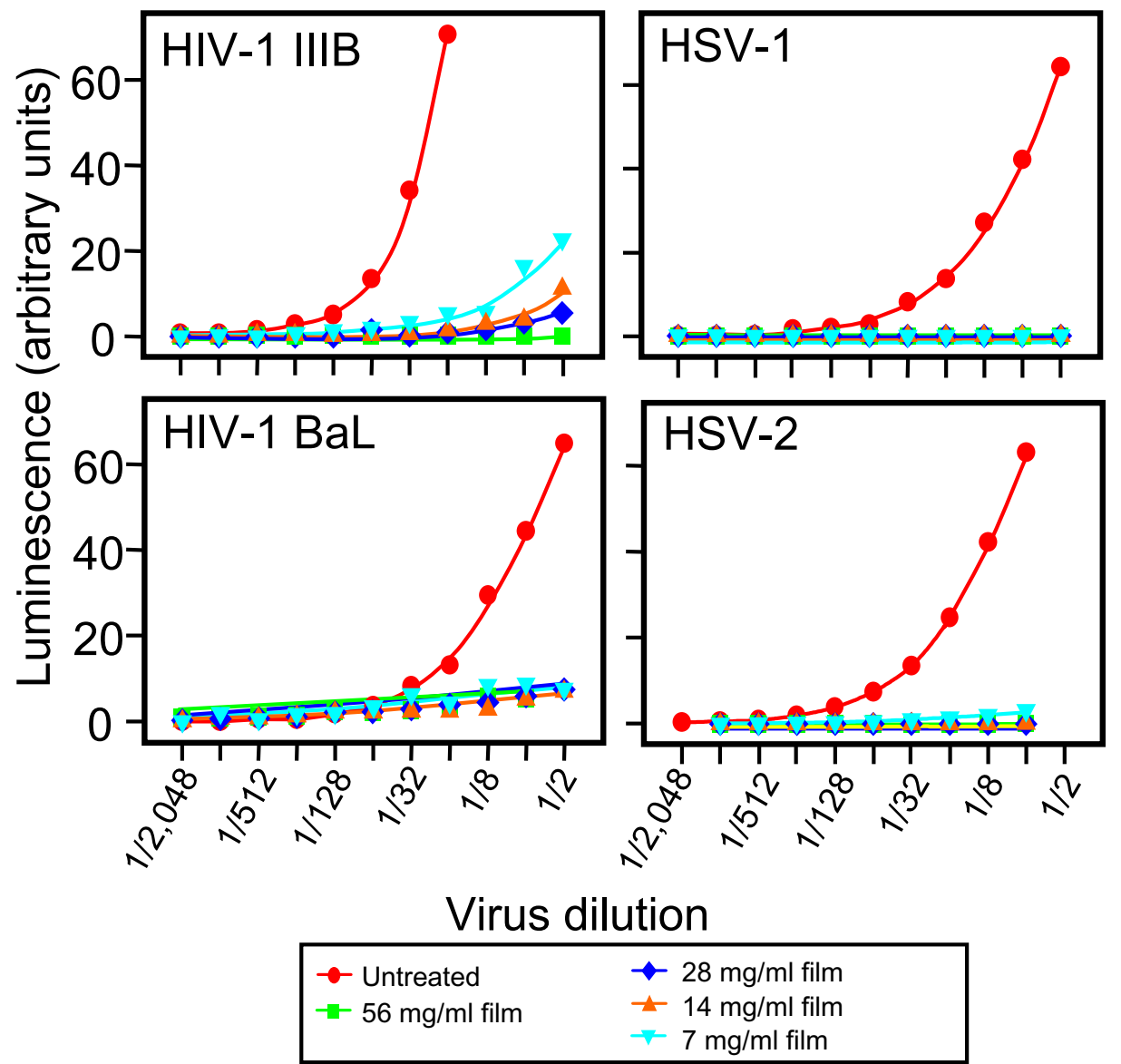

Figure 2

Inactivation of HIV-I IIIB, HIV-I BaL and HSV-I and HSV-2 by graded quantities of film H. Serial dilutions of the respective control and film treated $\left(5 \mathrm{~min}\right.$ at $\left.37^{\circ} \mathrm{C}\right)$ viruses were added to cells and virus replication was monitored by measuring $\beta$-gal activity.

\section{Discussion}

To the best of our knowledge, the CAP film is presently the first film formulation for a candidate microbicide after the failure of an $\mathrm{N}-9$ containing contraceptive film in phase III clinical trials for efficacy against sexual transmission of HIV-1. The likelihood of genital lesions after vaginal application of this film has been reported $[31,59]$. This has led to the misconception among some researchers in the microbicide field that films, rather than the film ingredients, are responsible for the untoward effects observed. In fact, undesirable proinflammatory effects induced by $\mathrm{N}-9$ have been documented in in vitro experiments $[60,61]$ and in cervicovaginal lavages from women after application of an N-9 containing gel [60,61]. Inflammatory responses induced by $\mathrm{N}-9$ were seen in animal model experiments [62] \{S. Hild personal communication $\}$ and in women after vaginal application of $\mathrm{N}-9$ [32,63,64]. On the other hand, untoward effects have not been seen when CAP was used in in vitro [61] or animal model experiments [65] (S. Hild, personal communication). CAP based gels have received regulatory approval in the United Kingdom for phase I clinical trials based on the latter findings. Thus, there is a priori no reason to believe that CAP films will elicit undesirable effects.

Difficulties in applying the N-9 film have been reported anecdotically since the film appeared to stick to wet fingers. This does not seem to apply to CAP films. The optimization of CAP films in iterative human acceptance trials is expected to obviate problems of this kind. 


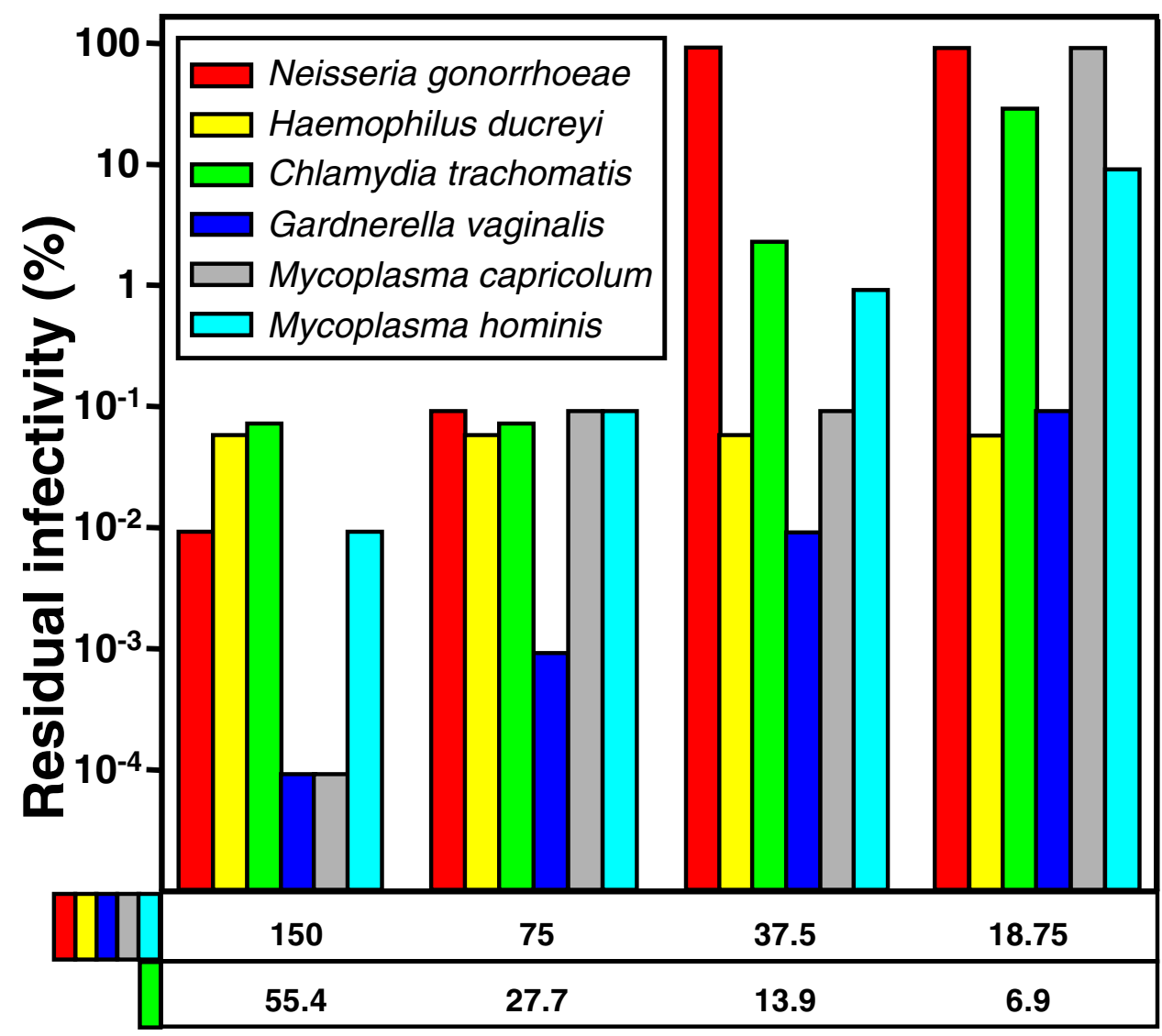

Film H dosage $(\mathrm{mg} / \mathrm{ml})$

Figure 3

Inactivation by film $\mathrm{H}$ of selected non-viral STD pathogens and bacteria associated with BV. The STD pathogens (Neisseria gonorrhoeae, Haemophilus ducreyi and Chlamydia trachomatis) and bacteria associated with BV (Gardnerella vaginalis, Mycoplasma capricolum and Mycoplasma hominis) were treated with graded quantities of film $\mathrm{H}$ for $5 \mathrm{~min}$ at $37^{\circ} \mathrm{C}$. Note on the abscissa that film dosages for Chlamydia trachomatis were different from those used for the other bacteria.

The CAP-HPC composite film after contact with water or physiological fluids is progressively converted into a gel (Fig. 1d). Similar gels were shown earlier [7,8,12-14] to rapidly inactivate HIV-1, HSV and other STD pathogens. Upon contact with fluids containing STD pathogens, the film inactivated the respective viruses and/or bacteria rapidly, long before it was converted into a gel. Expected exposure to high sheer rates during physiological processes would result in more rapid disintegration and conversion of the film into a gel than shown in Fig. 1d. Tests in animal model systems and human clinical trials will be needed to determine whether the film is efficacious in vivo.
Similarly to CAP based gels [10], the CAP-HPC film was active against several bacteria associated with BV, known to increase susceptibility to HIV-1 infection [46]. Thus inserted CAP-HPC films might be candidates for treatment of BV.

In addition to their application as a topical microbicide the described bioadhesive CAP-HPC films could be useful for delivery of pharmaceuticals to mucosal surfaces, including oral and ophthalmic $[66,67]$ applications.

Scaling up the film production on continuous belts, the selection of optimal size, thickness, shapes, folding, and appropriate packaging of the films for distinct applications will require further studies. 
The CAP-HPC composite can be dried from organic solvent mixtures containing EtOH (as described above) in physical forms other than a film, e.g. granules, combined with tablet disintegrants (Mannogem or Pharmaburst [SPI Pharma, Grand Haven, MI, USA]) and compressed into tablets. The tablets in contact with water disintegrate instantaneously and are subsequently converted into a smooth gel similar to that generated by the films (Fig. 1d). Such tablets extend the potential application of the CAPHPC composite as a topical microbicide and drug delivery tool. In general, the described composite contributes to broadening the function of CAP from an enteric coating material to becoming a component of novel mucosal drug delivery systems with inherent anti-microbial properties.

\section{Conclusions}

Microbicidal gels are being widely considered and developed as tools to prevent the sexual transmission of HIV-1 and other STD pathogens. A CAP based gel for this purpose has been developed [7-14] and is advancing into phase 1 human clinical trials. Such gels require applicators for topical delivery. This adds to the cost of the final product and may cause disposal problems and environmental concerns. These disadvantages can be overcome by replacing the gels with unit dose biodegradable devices dispersible in physiological fluids. We describe here a novel method to produce composite films in which the active ingredient, CAP, is an integral structural component. The film absorbs water and disintegrates leading to the formation of micronized CAP particles which were shown to adsorb HIV-1 [14] and inactivate STD pathogens. The film is converted in contact with physiological fluids into a soft gel, thus obviating the need for delivery by applicators. The CAP-HPC composite film could be useful for delivery to mucosal surfaces of pharmaceuticals other than CAP. Combined with other excipients, the shredded composite film can be compressed into tablets which disintegrate instantaneously, providing an alternative microbicide and general drug delivery system.

\section{Abbreviations used}

CAP, cellulose acetate phthalate; HIV, human immunodeficiency virus; HSV, herpes viruses; STD, sexually transmitted disease; AIDS, acquired immunodeficiency syndrome; HPC, hydroxypropyl cellulose; EtOH, ethanol; $\beta$-gal, $\beta$ galactosidase; $\mathrm{BV}$, bacterial vaginosis.

\section{Competing Interests}

None declared.

\section{Authors' contributions}

ARN developed the concepts representing the basis of the manuscript and designed most experiments. NS contributed to the development of the film and tablets and carried out experiments other than infectivity assays. YYL did all the tissue culture work and viral and bacterial infectivity assays.

\section{Acknowledgements}

This study was supported by NIH grant (POI HD4I76I) and the Marilyn M. Simpson Charitable Trust and is dedicated to the memory of Dr. Maurice Cohen, in appreciation of his enthusiastic support of research on biodegradable devices. We thank Veronica Kuhlemann for preparation of the manuscript and Figures. Scanning electron microscopy experiments were done by Richard S. Brown, MVA, Inc., Norcross, Georgia, USA. CAP and the tablet disintegrants Mannogem and Pharmaburst were gifts from Eastman Chemical Company (Kingsport, Tennessee, USA), and SPI Pharma (Grand Haven, Michigan, USA), respectively. HeLa-CD4-LTR- $\beta$-gal and MAGI-CCR5 cells were obtained from the AIDS Reagent and Reference Reagent Program (Rockville, Maryland, USA) contributed by Drs. M. Emerman and J. Overbaugh. HSV-I vgCL5 was a gift from Dr. J. P. Weir.

\section{References}

I. Liao J, Ottenbrite RM: Biological effects of polymeric drugs. Controlled Drug Delivery Edited by: ParkK. Washington,DC, American Chemical Society; 1997:455-467.

2. Uglea CV, Panaitescu L: Synthetic polyanionic macromolecules with antiviral and antitumoral activity. Current Trends in Polymer Science 1997, 2:24I-25I.

3. Biomedical Polymers and Polymer Therapeutics. Volume 200I. Edited by: ChielliniE, SunamotoJ, MigliaresiC, OttenbriteRM and CohnD. Dordrecht, NL, Kluwer Academic/Plenum Publishers; 200 I.

4. Duncan R: The dawning era of polymer therapeutics. Nat Rev Drug Discov 2003, 2:347-360.

5. Kabanov AV, Okano T: Challenges in polymer therapeutics: State of the art and prospects of polymer drugs. Polymer drugs in the clinical stage Edited by: MaedaH, KabanovA, KataokaK and OkanoT. New York, Kluwer Academic/Plenum Publishers; 2003:I-27.

6. Stone A: Microbicides: A new apporach to preventing HIV and other sexually transmitted infections. Nat Rev Drug Discov 2002, 1:977-985.

7. Neurath AR, Strick N, Li Y-Y, Lin K, Jiang S: Design of a "microbicide" for prevention of sexually transmitted diseases using "inactive" pharmaceutical excipients. Biologicals 1999, 27: I I-2I.

8. Gyotoku T, Aurelian L, Neurath AR: Cellulose acetate phthalate (CAP): an 'inactive' pharmaceutical excipient with antiviral activity in the mouse model of genital herpesvirus infection. Antiviral Chem Chemother 1999, 10:327-332.

9. Manson KH, Wyand MS, Miller C, Neurath AR: The effect of a cellulose acetate phthalate topical cream on vaginal transmission of simian immunodeficiency virus in rhesus monkeys. Antimicrob Agents Chemother 2000, 44:3199-3202.

10. Neurath $A R, L i$ Y - Y, Mandeville R, Richard $L$ : In vitro activity of a cellulose acetate phthalate topical cream against organisms associated with bacterial vaginosis. J Antimicrob Chemother 2000, 45:7|3-7|4

II. Kawamura T, Cohen SS, Borris DL, Aquilino EA, Glushakova S, Margolis LB, Orenstein JM, Offord RE, Neurath AR, Blauvelt A: Candidate microbicides block HIV-I infection of human immature Langerhans cells within epithelial tissue explants. J Exp Med 2000, 192: | $49 \mid-1500$.

12. Neurath AR, Strick N, Li Y-Y, Debnath AK: Cellulose acetate phthalate, a common pharmaceutical excipient, inactivates HIV-I and blocks the coreceptor binding site on the virus envelope glycoprotein gp I 20. BMC Infect Dis 200I, I: I7.

13. Neurath AR, Strick N, Jiang S, Li YY, Debnath AK: Anti-HIV-I activity of cellulose acetate phthalate: Synergy with soluble CD4 and induction of "dead-end" gp4 I six-helix bundles. BMC Infect Dis 2002, 2:6.

14. Neurath AR, Strick N, Li Y-Y: Anti-HIV-I activity of anionic polymers: A comparative study of candidate microbicides. BMC Infect Dis 2002, 2:27.

15. Goskonda SR, Lee JC: Cellulose Acetate Phthalate. Handbook of Pharmaceutical Excipients Third Editionth edition. Edited by: KibbeAH. Washington, D.C./London,U.K., American Pharmaceutical Association/Pharmaceutical Press; 2000:99-101. 
16. Banker GS: Pharmaceutical coating composition, and preparation and dosages so coated. . US Patent 4,330,338 issued May 181982

17. McGinley EJ, Tuason DC Jr: Enteric coating for pharmaceutical dosage forms. . US Patent 4,5 I 8,433 issued May 2I 1985

18. McGinley EJ: Enteric coating for pharmaceutical dosage forms. . European Patent 0 II I 103 issued September 201989

19. Wu SHW, Greene CJ, Sharma MK: Water-dispersible polymeric compositions. . US Patent 4,960,8I4 issued October 21990

20. Wu SHW, Greene CJ, Sharma MK: Water-dispersible polymeric compositions. . US Patent 5,025,004 issued June I8 I99 I

21. Sakellariou P, Rowe RC: Phase separation and morphology in ethylcellulose/cellulose acetate phthalate blends. J Applied Polymer Science 1991, 43:845-855.

22. Ibrahim H, Bindschaedler C, Doelker E, Buri P, Gurny R: Aqueous nanodispersions prepared by a salting-out process. Int J Pharm 1992, 87:239-246.

23. Quintanar-Guerrero D, Allemann E, Fessi H, Doelker E: Pseudolatex preparation using a novel emulsion-diffusion process involving direct displacement of partially water-miscible solvents by distillation. Int J Pharm 1999, 188:155-164.

24. Yuan J, Wu SHW: Process for production of polymeric powders. . US Patent 6,54I,542 issued April I 2003

25. Stiasny K, Koessl C, Heinz FX: Involvement of lipids in different steps of the flavivirus fusion mechanism. J Virol 2003 77:7856-7862.

26. Kietzke T, Neher D, Landfester K, Montenegro R, Guntner R, Scherf $\mathrm{U}$ : Novel approaches to polymer blends based on polymer nanoparticles. Nat Mater 2003, 2:408-4I2.

27. Heusser J, Martin M: Pharmaceutical, vaginal applicable preparation and a process for its preparation. . US Patent $\mathbf{5 , 3 8 0 , 5 2 9}$ issued January 101995

28. Meyers M: Use of edible film to prolong chewing gum shelf life. US Patent 5,409,7I5 issued April 251995

29. Staab R: Dissolvable device for contraception or delivery of medication. . US Patent 5,529,782 issued June 251996

30. Thombre AG, Wigman LS: Rapidly disintegrating and fast-dissolving solid dosage form. . US Patent $\mathbf{6 , 4 9 7 , 8 9 9}$ issued December 242002

31. Roddy RE, Zekeng L, Ryan KA, Tamoufe U, Weir SS, Wong EL: A controlled trial of nonoxynol 9 film to reduce male-to-female transmission of sexually transmitted diseases. $N$ Engl J Med 1998, 339:504-510

32. Van Damme L, Ramjee G, Alary M, Vuylsteke B, Chandeying V, Rees $\mathrm{H}$, Sirivongrangson P, Mukenge-Tshibaka L, Ettiegne-Traore V, Uaheowitchai C, Abdool Karim SS, Masse B, Perriens J, Laga M: Effectiveness of COL-1492, a nonoxynol-9 vaginal gel, on HIV-I transmission in female sex workers. The Lancet 2002, 360:97|-977.

33. Green G, Pool R, Harrison S, Hart G], Wilkinson J, Nyanzi S, Whitworth JA: Female control of sexuality: illusion or reality? Use of vaginal products in south west Uganda. Soc Sci Med 200I, 52:585-598.

34. Jones DL, Weiss SM, Malow R, Ishii M, Devieux J, Stanley H, Cassells A, Tobin JN, Brondolo E, LaPerriere A, Efantis-Potter J, O'Sullivan MJ, Schneiderman N: A brief sexual barrier intervention for women living with AIDS: acceptability, use, and ethnicity. J Urban Health 200I, 78:593-604.

35. Mann JM, Tarantola DJM, Netter TW: AIDS in the World Edited by: MannJM, TarantolaDJM and NetterTW. Cambridge, Harvard University Press; 1992.

36. Perine PL: Sexually transmitted diseases in the tropics. Medical Journal of Australia 1994, 160:358-366.

37. HIV prevention through early detection and treatment of other sexually trasmitted diseases -- United States Recommendations of the Advisory Committee for HIV and STD Prevention. Mor Mort Wkly Rep 1998, 47:I-24.

38. Over $M$, Piot $P$ : Human immunodeficiency virus infection and other sexually transmitted diseases in developing countries: public health importance and priorities for resource allocation. J Infect Dis 1996, I74:SI62-SI75.

39. Rottingen JA, Cameron DW, Garnett GP: A systematic review of the epidemiologic interactions between classic sexually transmitted diseases and HIV: how much really is known? Sex Transm Dis 200I, 28:579-597.
40. Coggins C, Segal S: AIDS and reproductive health. J Reprod Immunol 1998, 41:3-15.

4I. Holmberg SD, Stewart JA, Gerber AR, Byers RH, Lee FK, O'Malley $\mathrm{PM}, \mathrm{Nahmias} A$ ): Prior herpes simplex virus type $\mathbf{2}$ infection as a risk factor for HIV infection. JAMA 1988, 259: I048-1050.

42. Reynolds SJ, Risbud AR, Shepherd ME, Zenilman JM, Brookmeyer RS, Paranjape RS, Divekar AD, Gangakhedkar RR, Ghate MV, Bollinger RC, Mehendale SM: Recent herpes simplex virus type 2 infection and the risk of human immunodeficiency virus type I acquisition in India. J Infect Dis 2003, 187:1513-1521.

43. Ramjee G, Gouws E, Van Dyke E, Williams B, Karim SA: Herpes simplex virus type II infection is a risk factor for HIV seroconversion. Medical Research Council Policy Brief Volume August. Durban, South Africa, Medical Research Council; 2002.

44. Gerbase AC, Rowley JT, Heymann DHL, Berkley SFB, Piot P: Global prevalence and incidence estimates of selected curable STDs. Sex Transm Dis 1998, 74 (SuppI I):SI2-SI6.

45. Nahmias AJ, Lee FK, Beckman-Nahmias S: Sero-epidemiological and -sociological patterns of herpes simplex virus infection in the world. Scand J Infect Dis Suppl 1990, 69:19-36.

46. Martin H.L.,Jr., Richardson BA, Nyange P, Lavreys L, Hillier SL, Chohan B, Mandaliya K, Ndinya-Achola JO, Bwayo J, Kreiss J: Vaginal lactobacilli, microbial flora, and risk of human immunodeficiency virus type $I$ and sexually transmited disease acquisition. J Infect Dis 1999, 180: 1863-1868.

47. Neurath AR: A microbicide for prevention of sexually transmitted diseases using a pharmaceutical excipient. AIDS Patient Care STDS 2000, 14:215-219.

48. Neurath AR, Stick N, Li Y-Y, Radigan L, Jiang S: A microbicide for the third millenium (cellulose acetate phthalate). XIII International AIDS Conference 2000:713-7I7.

49. Neurath AR, Strick N: Quantitation of cellulose acetate phthalate in biological fluids as a complex with ruthenium red. Anal Biochem 2001, 288: 102-104.

50. Harwood RJ: Hydroxypropyl cellulose. Handbook of pharmaceutical excipients Volume 244. Thirdth edition. Edited by: KibbeAH. Washington,DC; London,UK, American Pharmaceutical Association, Pharmaceutical Press; 2000:244-248.

51. Tambweker KR, Gunjan VK, Kandarapu R, Zaneveld LJD, Garg S: Effect of different bioadhesive polymers on performance characteristics of vaginal tablets. Microbicides 2002 Conference Abstract 2002, I5:.

52. Arwidsson $\mathrm{H}$, Johansson $\mathrm{B}$ : Application of intrinsic-viscosity and interaction constant as a formulation tool for film coating. 3 . Mechanical studies on free ethyl cellulose films, cast from organic-solvents. Int J Pharm 1991, 76:91-97.

53. Jones DS, Medlicott NJ: Casting solvent controlled release of chlorhexidine from ethyl cellulose films porepared by solvent evaporation. Int J Pharm 1995, I I 4:257-26I.

54. Rosilio V, Roblot-Treupel L, De Lourdes Costa M, Baszkin A: Physicochemical characterization of ethyl cellulose drug-loaded cast films. J Control Release 1988, 7:171-180.

55. Kovacs B, Nguyen VH, Racz I: Studies on drug film coatings. Part 2. Flexibiility of coatings. Acta Pharm Hungarica 1985, 55:205-2 I I.

56. Vemba T, Gillard J, Roland M: Influence of solvents and plasticizers on the permeability and the rupture force of ethyl cellulose film coatings. Pharmaceutica Acta Helvetiae 1980, 55:65-7I.

57. Dyer JR, Kazembe P, Vernazza PL, Gilliam BL, Maida M, Zimba D, Hoffman IF, Royce RA, Schock JL, Fiscus SA, Cohen MS, Eron J.J.,Jr.: High levels of human immunodeficiency virus type $I$ in blood and semen of seropositive men in sub-Saharan Africa. J Infect Dis 1998, 177: 1742-1746.

58. Chakraborty H, Sen PK, Helms RW, Vernazza PL, Fiscus SA, Eron JJ, Patterson BK, Coombs RW, Krieger JN, Cohen MS: Viral burden in genital secretions determines male-to-female sexual transmission of HIV-I: a probabilistic empiric model. AIDS 200I, I5:621-627.

59. Rustomjee R, Abdool Karim A, Abdool Karim SS, Laga M, Stein Z: Phase I trial of nonoxynol-9 film among sex workers in South Africa. AIDS 1999, 13:15II-1515.

60. Fichorova RN, Tucker LD, Anderson DJ: The molecular basis of nonoxynol-9-induced vaginal inflammation and its possible relevance to human immunodeficiency virus type I transmission. J Infect Dis 200I, 184:4I8-428.

6I. Fichorova RN, Zhou F, Spangler M, Strick N, Neurath AR: Effects of cellulose acetate phthalate on proinflammatory activation 
status of human cervicovaginal epithelial cells. Microbicides 2003 Conference Abstract 2003:A49.

62. Milligan GN, Dudley KL, Bourne N, Reece A, Stanberry LR: Entry of inflammatory cells into the mouse vagina following application of candidate microbicides: Comparison of detergentbased and sulfated polymer-based agents. Sex Transm Dis 2002, 29:597-605.

63. Stafford MK, Ward H, Flanagan A, Rosenstein IJ, Taylor-Robinson D, Smith JR, Weber J, Kitchen VS: Safety study of nonoxynol-9 as a vaginal microbicide: evidence of adverse effects. J Acquir Immune Defic Syndr Hum Retrovirol 1998, 17:327-33I.

64. Rosenstein IJ, Stafford MK, Kitchen VS, Ward H, Weber IN, TaylorRobinson D: Effect on normal vaginal flora of three intravaginal microbicidal agents potentially active against human immunodeficiency virus type I. J Infect Dis 1998, 177: I 386-1390.

65. Ratterree M, Gettie A, Malenbaum S, Neurath AR, Blanchard J, Cheng-Mayer C: Safety, distribution and protective efficacy of CAP in vivo. Microbicides 2003 Conference Abstract 2003:A48.

66. Gates KA, Grad H, Birek P, Lee PI: A new bioerodible polymer insert for the controlled release of metronidazole. Pharm Res 1994, I I:1605-1609.

67. Baeyens V, Kaltsatos V, Boisrame B, Fathi M, Gurny R: Evaluation of soluble Bioadhesive Ophthalmic Drug Inserts (BODI) for prolonged release of gentamicin: Lachrymal pharmacokinetics and ocular tolerance. J Ocul Pharmacol Ther 1998, 14:263-272.

\section{Pre-publication history}

The pre-publication history for this paper can be accessed here:

http://www.biomedcentral.com/1471-2334/3/27/prepub

Publish with Bio Med Central and every scientist can read your work free of charge

"BioMed Central will be the most significant development for disseminating the results of biomedical research in our lifetime. "

Sir Paul Nurse, Cancer Research UK

Your research papers will be:

- available free of charge to the entire biomedical community

- peer reviewed and published immediately upon acceptance

- cited in PubMed and archived on PubMed Central

- yours - you keep the copyright 